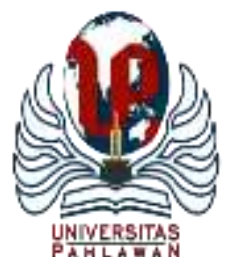

\title{
JURNALBASICEDU
}

Volume 6 Nomor 1 Tahun 2022 Halaman 738 - 748

Research \& Learningin Elementary Education

https://jbasic.org/index.php/basicedu

\section{Impelementasi Kurikulum Merdeka Belajar Kampus Merdeka (MBKM) berdasarkan Persepsi Dosen dan Mahasiswa}

\author{
Abdul Kholik ${ }^{1 凶}$, Hasan Bisri ${ }^{2}$, Zahra Khusnul Lathifah ${ }^{3}$, Berliana Kartakusuma ${ }^{4}$, \\ Mustolah Ma'ufur', Teguh Prasetyo ${ }^{6}$ \\ Program Studi Manajemen Pendidikan Islam, Universitas Djuanda Bogor, Indonesia ${ }^{1,2,3,4,5}$, \\ Pendidikan Guru Sekolah Dasar, Universitas Djuanda Bogor, Indonesia ${ }^{6}$ \\ E-mail: abdul.kholik@unida.ac.id ${ }^{1}$, hasan.bisri1969@yahoo.co.id ${ }^{2}$, lalthifazahra@gmail.com ${ }^{3}$,

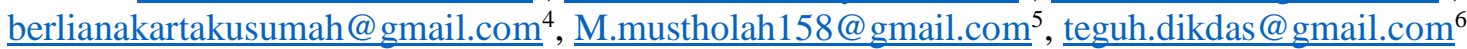

\begin{abstract}
Abstrak
Implementasi pembelajaran kurikulum Merdeka Belajar Kampus Merdeka telah diluncurkan pada tahun 2020. Kurikulum MBKM menjadi tantangan nyata bagi setiap universitas untuk memberikan respons positif terhadap wajah kurikulum baru ini. Penelitian ini bertujuan untuk menggambarkan persepsi dosen dan mahasiswa dalam program studi manajemen pendidikan Islam di Universitas Djuanda yang terkait dengan menerapkan kurikulum MBKM. Pendekatan penelitian yang digunakan secara kualitatif dengan metode studi kasus. Teknik pengumpulan data menggunakan kuesioner dan wawancara untuk meneliti informan kunci. Proses analisis data hasil penelitian dilakukan secara deskriptif dan triangulasi sumber penelitian. Hasil pelaksanaan kurikulum MBKM menunjukkan bahwa persepsi dosen tentang (1) penyusunan kurikulum MBKM dan minat dalam program MBKM, (2) peningkatan kapasitas dosen dalam pembelajaran, (3) memperluas proses pembelajaran bersama mahasiswa, (4) peningkatan hard skills dan soft skills mahasiswa. Sedangkan pada aspek mahasiswa 61,6\% telah mempersiapkan diri untuk mengambil bagian dalam program MBKM, dan $7 \%$ mahasiswa menyatakan bahwa ada peningkatan hard skills dan soft skills melalui program MBKM. Hasil penelitian memberikan informasi bahwa hambatan implementasi kurikulum MBKM memiliki empat hal utama, yaitu; penyesuaian kurikulum, pendanaan, penjajagan mitra, dan penyesuaian sistem informasi akademik. Oleh karena itu, implikasi dari implementasi MBKM perlu direncanakan, dilaksanakan, dan dievaluasi secara bersama baik dari pemerintah, dan program studi sebagai garda terdepan dalam melaksanakan kurikulum MBKM.
\end{abstract}

Kata Kunci: implementasi, kurikulum, merdeka belajar kampus merdeka, persepsi dosen dan mahasiswa

\begin{abstract}
Learning Implementation of Merdeka Learning Curriculum Learning Kampu Merdeka was launched in 2020. The MBKM curriculum is a real challenge for every university to respond to the face of this new curriculum positively. This study aims to describe the perceptions of lecturers and students in the Islamic Education Management Study Program at Djuanda University related to implementing the MBKM curriculum. The research approach used qualitatively with case study methods. Data collection techniques use questionnaires and interviews to examine key informants. The process of analyzing data from the study results was conducted descriptively and triangulation of research sources. The results of the MBKM curriculum indicate that the perception of lecturers about (1) the preparation of the MBKM curriculum and interest in the MBKM program, (2) Increasing the capacity of lecturers in learning, (3) expanding the learning process with students, (4) increased hard skills and student soft skills. Whereas in the aspects of students, 61.6\% have prepared themselves to take part in the MBKM program, and 7\% of students state that there is an increase in hard skills and soft skills through the MBKM program. The results of the study provide information that the resistance of the implementation of the MBKM curriculum has four main things, namely; curriculum adjustments, funding, partner slaughter, and adjustment of academic information systems. Therefore, the implication of the implementation of MBKM needs to be planned, implemented, and jointly evaluated both by the government, and the study program as the front guard in implementing the MBKM curriculum.
\end{abstract}

Keywords: Implementation, Curriculum, Merdeka Learn Merdeka Campus, Perception of Lecturers and Students

Copyright (c) 2022 Abdul Kholik, Hasan Bisri, Zahra Khusnul Lathifah, Berliana Kartakusuma, Mustolah Ma’ufur, Teguh Prasetyo

$\varangle$ Corresponding author :

Email : abdul.kholik@unida.ac.id

DOI : https://doi.org/10.31004/basicedu.v6i1.2045

ISSN 2580-3735 (Media Cetak)

ISSN 2580-1147 (Media Online) 


\section{PENDAHULUAN}

Salah satu kompetitif sebuah lembaga pendidikan adalah kemampuan dalam menyikapi tantangan dan kecenderungan zaman yang ada dan terjadi saat ini (Suryaman, 2020). Perubahan memaksa universitas untuk melakukan penghitungan dengan konsekuensi yang matang dan menganalisis resiko yang akan dilakukan khusus di masa pandemik. Oleh karena itu, inovasi harus dilakukan guna mendukung efisiensi dan efektivitas sistem pendidikan berjalan baik di kampus. Salah satu aspek yang penting untuk melakukan inovasi adalah kurikulum pendidikan. Penerapan kebijakan pemerintah dibidang pendidikan secara otomatis akan berpengaruh manajemen kurikulum pada setiap jenjang pendidikan. Proses pelaksanaan harus beradaptasi di masing-masing perguruan tinggi terhadap penerapan kebijakan perubahan kurikulum dengan cara melakukan perubahan kurikulum dan penyesuaian kurikulum yang ada (Uswatiyah et al., 2021).

Perubahan kurikulum pada tingkat perguruan tinggi yang dilaksanakan dengan sebutan Merdeka Belajar Kampus Merdeka (MBKM) merupakan sebuah kebijakan Menteri Pendidikan dan Kebudayaan (Kemdikbud). Kebijakan perubahan kurikulum MBKM ini merupakan upaya mendorong mahasiswa dalam penguasaan berbagai keilmuan yang berguna untuk memasuki dunia kerja atau industri pada abad 21 dan Society 5.0. Konsep merdeka belajar sangat cocok di masa sekarang karena masyarakat 5.0 memadukan antara perkembangan kemajuan teknologi dapat membantu memecahkan masalah dan kebutuhan sosial hidup individu (Marisa, 2021). Oleh sebab itu, kebijakan merdeka belajar yang diharapkan mampu membuat dunia pendidikan tanpa beban dan adanya peran teknologi membantu mempengaruhi penyelesaian masalah kehidupan sosial.

Pada kurikulum MBKM, setiap mahasiswa diberikan kesempatan belajar interdisipliner dalam dan luar program studi bahkan universitas. Lebih lanjut mahasiswa diwajibkan belajar maksimal 40 SKS untuk belajar dan berlatih di luar kampus, ditambah lagi 20 SKS di luar prodi yang diatur dalam panduan kurikulum perguruan tinggi MBKM. Tujuannya mahasiswa tidak hanya unggul dari sisi akademis melainkan juga terampil dari sisi keterampilan yang diperlukan pasar (Hasim, 2020). Selain itu, implementasi kurikulum MBKM diharapkan dapat menjawab tantangan perkembangan teknologi dengan pendidikan sistem pembelajaran berbasis OBE (Outcome Based Education) sehingga lulusannya fokus terhadap capaian pembelajaran yang selaras sesuai dengan disiplin ilmu (Sopiansyah et al., 2022).

Implementasi kurikulum MBKM harus dikembangkan oleh setiap perguruan tinggi dan program studi. Tantangan ini harus dihadapi dengan mempersiapkan pengembangan kurikulum program studi dengan mengadaptasi kebijakan MBKM meliputi aspek perencanaan, proses pembelajaran, penilaian, dan evaluasi pembelajaran (Baharuddin, 2021). Selain itu, dalam mengambangkan kurikulum di program studi harus memperhatikan profil lulusan dan Capaian Pembelajaran (CPL) yang sesuai konten belajar dengan tantangan di masa yang akan datang. Kurikulum MBKM harus memberikan pengalaman belajar bermakna bagi mahasiswa selaku peserta didik dengan memberikan kebebasan dalam belajar akademik dan non akademik serta secara komprehensif perlu melibatkan seluruh pemangku kepentingan yang ada di universitas mulai dari para pimpinan, dosen, mahasiswa, alumni, dan pengguna (Suwandi, 2020).

Mengutip apa yang dituliskan dalam artikel Susetyo, (2020) pelaksanaan Merdeka Belajar Kampus Merdeka banyak mengalami kendala. Beberapa kendala yang diungkapkan antara lain; (1) tujuan pendidikan, (2) panduan pelaksanaan kurikulum Merdeka Belajar Kampus Belajar, (3) pola pikir, (4) penyusunan kurikulum di program studi, (5) kerja sama dengan perguruan tinggi lain (6) kerja sama dengan lembaga lain, industri atau perusahaan, (7) pengambilan mata kuliah di prodi lain di perguruan tinggi sendiri maupun di perguruan tinggi lain, (8) pelaksanaan praktik di industri atau perusahaan, (9) dana yang diperlukan untuk praktik atau magang bagi mahasiswa, (10) sistem administrasi akademik, (11) dana yang diperlukan untuk praktik atau magang bagi mahasiswa, (12) pandemi Covid 19, dan (13) penyiapan SDM. Hal yang senada 
berkaitan dengan kendala implementasi MBKM misalnya mekanisme kolaborasi antara perguruan tinggi atau program studi dengan pihak luar kampus yang berbadan hukum, perubahan kampus negeri menjadi PTN berbadan hukum dan pelaksanaan magang di luar program studi, karakteristik pendidikan Indonesia sebelumnya, kondisi geografis (Sabriadi \& Wakia, 2021).

Berdasarkan fakta di lapangan dalam implementasi awal kurikulum MBKM tidak secara langsung dapat berjalan dengan baik. Misalnya hasil penelitian Aji \& Putra, (2021), diungkapkan fakultas harus mengambil langkah penentuan pelaksanaan kegiatan di semester yang dirasa sesuai dengan proses pengajaran dan pembelajaran yang ada di lingkungan kampus sehingga kurikulum yang dirancang dapat berdampak kepada keefektifitasan dan efisiensi pelaksanaan program MBKM. Solusi yang perlu dilakukan oleh setiap universitas adalah menyusun panduan bersama antar perguruan tinggi dalam pelaksanaan Kurikulum Merdeka Belajar Kampus Merdeka, membuat pedoman dan kesepakatan kerja sama dengan perguruan tinggi lain, lembaga lain, perusahaan, dan industri, serta menyosialisasikan Kurikulum MBKM kepada dosen dan mahasiswa (Susetyo, 2020).

Penelitian ini dilatarbelakangi pada tantangan dan kendala-kendala di atas yang dihadapi pula oleh banyak perguruan tinggi terkait implementasi kurikulum MBKM yang telah ditetapkan pemerintah. Universitas Djuanda (UNIDA) yang terletak di Bogor merupakan universitas swasta yang aktif dan partisipatif terhadap program-program yang dirancang dan dilaksanakan oleh pemerintah. Keaktifan dan partisipasi Universitas Djuanda dapat diamati dengan hibah pada program-program penelitian dan pengabdian kepada masyarakat yang dilakukan para dosen dan mahasiswa. Selanjutnya tujuan dari penelitian ini adalah untuk mendeskripsikan persepsi mahasiswa dan dosen di Program Studi Manajemen Pendidikan Islam (MPI) berkaitan dengan implementasi Kurikulum MBKM yang telah bergulir selama 1,5 tahun di Universitas Djuanda.

\section{METODE PENELITIAN}

Penelitian ini dilakukan dengan pendekatan kualitatif dengan metode studi kasus. Tujuan penelitian studi kasus untuk memberikan deskripsi telah digunakan di bidang psikologi, baik psikologi industri dan organisasi, psikologi pendidikan, maupun psikologi sosial (Prihatsanti et al., 2018). Kasus yang diambil tentang implementasi kurikulum MBKM yang dilakukan program studi MPI berdasarkan persepsi dosen dan mahasiswa yang telah diterapkan 1,5 tahun. Prosedur penelitian dilaksanakan dengan melakukan penyebaran kuesioner kepada para responden, yakni mahasiswa dan dosen. Data kuesioner ini menjadi data awal yang diolah secara deskriptif sesuai tujuan penelitian dan bagaimana persepsi implementasi kurikulum MBKM di program studi MPI.

Adapun responden dan narasumber yang digunakan berjumlah 9 dosen dan 73 mahasiswa. Penelitian ini dilaksanakan pada bulan November dan Desember 2021, yakni pada semester gasal tahun akademik 2021/2022. Prosedur pengumpulan data dilakukan melalui angket karena kondisi masih pandemik dan wawancara terhadap narasumber penelitian. Kuesioner disusun mengacu pada indikator-indikator evaluasi implementasi Kurikulum MBKM Kemdikbud. Untuk memberikan informasi utama tentang implementasi maka dilakukan wawancara kepada dosen dan mahasiswa yang menjadi informan kunci dalam penelitian ini. Selanjutnya analisis penelitian dilakukan secara deskriptif dan triangulasi sumber pengumpulan data. 

dan Mahasiswa - Abdul Kholik, Hasan Bisri, Zahra Khusnul Lathifah, Berliana Kartakusuma, Mustolah Ma'ufur, Teguh Prasetyo

DOI: https://doi.org/10.31004/basicedu.v6i1.2045

\section{HASIL DAN PEMBAHASAN}

\section{Persiapan Implementasi MBKM bagi Dosen dan Mahasiswa}

Implementasi program MBKM di program studi MPI, telah direncanakan dan melibatkan pelaku utama proses kurikulum yakni dosen dan mahasiswa. Berdasarkan Dari hasil kuisioner dan wawancara terhadap responden didapatkan beberapa data mengenai keterlibatan dosen dan mahasiswa dalam kegiatan untuk penyiapan implementasi MBKM di prodi MPI yang dapat terlihat pada diagram berikut:

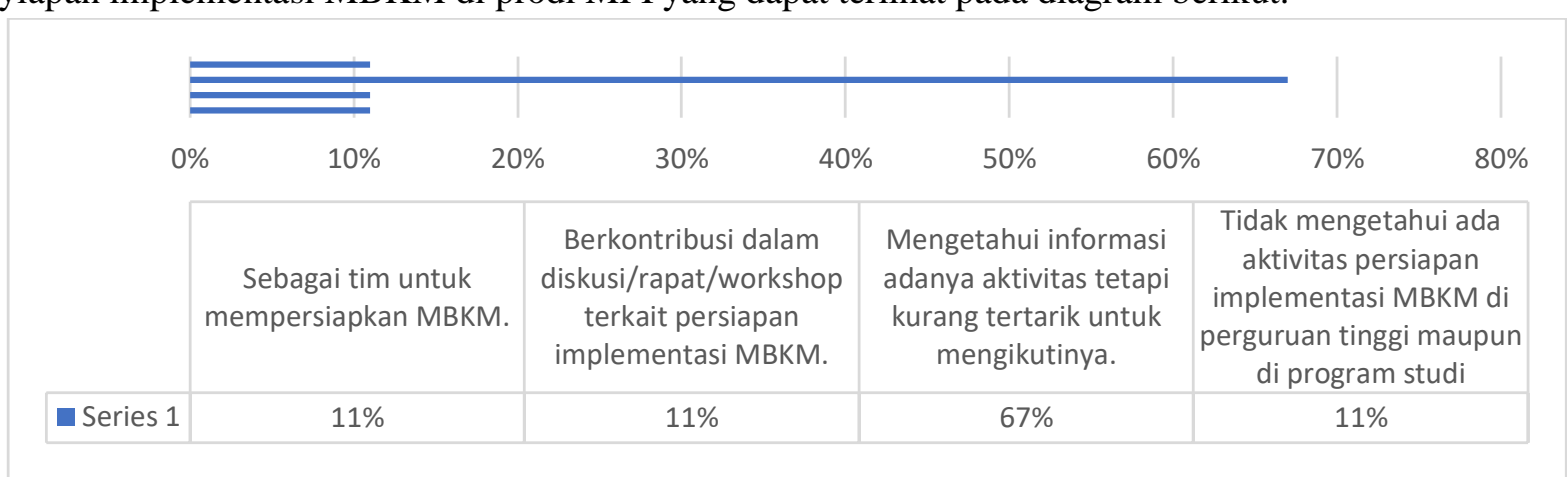

Diagram 1. Implementasi MBKM Penyiapan Dosen Di Program Studi

Berdasarkan diagram di atas, dapat dijelaskan bahwa 67\% dosen MPI FKIP UNIDA yang menjadi responden menyatakan mengetahui informasi adanya aktivitas MBKM tetapi kurang tertarik untuk mengikutinya. Setelah ditelusuri bahwa ternyata yang menjadi penyebab kurang tertariknya dosen dalam mengikuti kegiatan MBKM adalah minimnya informasi yang didapatkan secara utuh. Kemudian, 11\% menyatakan sebagai tim untuk mempersiapkan MBKM dan 11\% berkontribusi dalam diskusi/rapat/workshop terkait persiapan implementasi MBKM serta 11\% Tidak mengetahui ada aktivitas persiapan implementasi MBKM di perguruan tinggi maupun di program studi. Kemudian berdasarkan temuan yang berbeda berdasarkan sisi persepsi mahasiswa terkait penyiapan implementasi MBKM di prodi MPI. Dari 73 responden, 61,6\% atau 45 mahasiswa menyatakan sudah menyiapkan diri untuk menjadi bagian dalam kegiatan MBKM dan 35,6\% menyatakan belum, dan hanya 0,27\% yang menyatakan tidak berminat.

Persiapan yang lebih terencana dan sistematis bagi para dosen agar implementasi MBKM berjalan optimal menjadi sesuatu yang mutlak dan perlu. Selanjutnya dosen perlu mempersiapkan beberapa hal diantaranya adalah: (1) merancang kegiatan MBKM bersama mitra, (2) meyakinkan keselarasan CPL dengan kegiatan dan penilaiannya, (3) menyiapkan proses pembimbingan, dan 4) menyiapkan mata kuliah yang akan diambil oleh program studi/perguruan tinggi lain. Menurut persepsi dosen MPI terkait persiapan yang harus dimiliki dosen. Tidak hanya dosen, mahasiswa juga perlu mempersiapkan diri agar implementasi MBKM di prodi MPI berjalan optimal, misalnya dosen harus mempelajari buku panduan MBKM, ikut dalam pengembangan kurikulum yang memfasilitasi MBKM, mengikuti seleksi kegiatan dan program-program yang mendukung Kurikulum MBKM dan proaktif dalam perubahan kegiatan pembelajaran yang sesuai. 

dan Mahasiswa - Abdul Kholik, Hasan Bisri, Zahra Khusnul Lathifah, Berliana Kartakusuma, Mustolah Ma'ufur, Teguh Prasetyo

DOI: https://doi.org/10.31004/basicedu.v6i1.2045

\section{Dampak Implementasi Program MBKM terhadap Peningkatan Kapasitas Dosen}

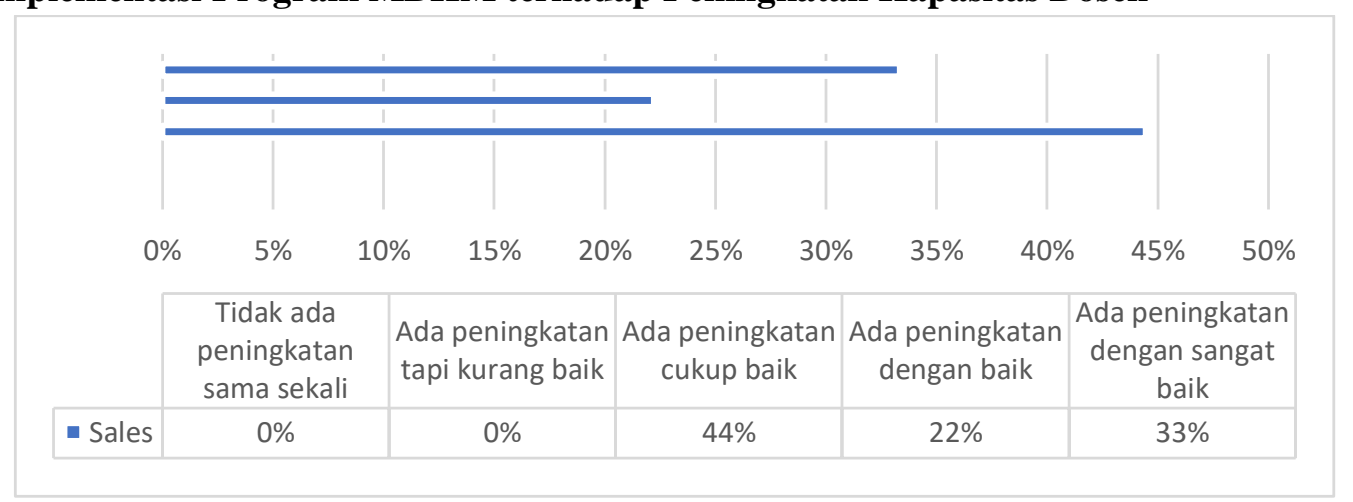

Diagram 2. Implementasi MBKM terhadap Peningkatan Kapasitas Dosen

Penerapan program MBKM tentunya tidak hanya dapat meningkatkan kualitas mahasiswa, tetapi juga dapat meningkatkan kapasitas dosen sebagai pengajar atau pendidik. Dosen dapat meningkatkan jejaring secara sosial, memperluas kemitraan baik kemitraan antar perguruan tinggi maupun industri, dosen dapat meningkatkan kreativitas dalam penelitian dan pengabdian masyarakat juga dalam pendidikan dan pengajaran, dosen dapat meningkatkan kreativitas dalam pemanfaatan teknologi informasi, serta dosen dapat meningkatkan profesionalisme. Hal itu sesuai dengan temuan penelitian terkait persepsi dosen mengenai peran implementasi program MBKM terhadap peningkatan kapasitas, ada $44 \%$ menyatakan ada peningkatan cukup baik, sebesar 22\% menyatakan ada peningkatan dengan baik, dan sebesar 33\% menyatakan ada peningkatan dengan sangat baik.

\section{Dampak Implementasi Program MBKM terhadap Proses Pembelajaran Mahasiswa}

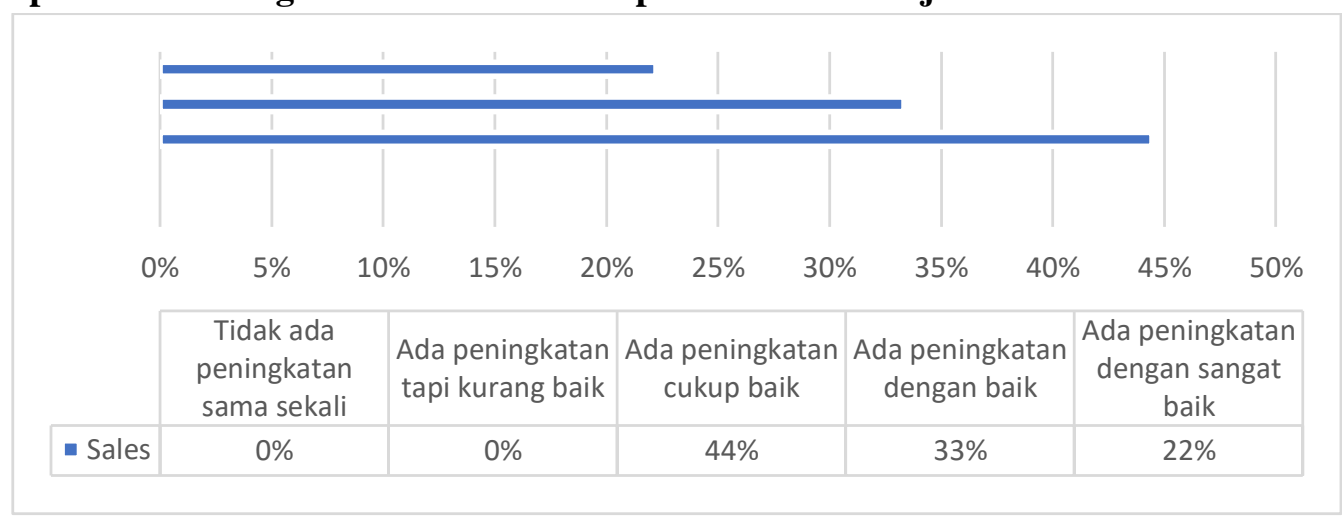

Diagram 3. Implementasi MBKM terhadap Pembelajaran Mahasiswa

Berdasarkan diagram di atas, mayoritas dosen MPI FKIP UNIDA Bogor menyatakan bahwa program MBKM berdampak terhadap proses pembelajaran mahasiswa. Sebanyak $44 \%$ menyatakan ada peningkatan cukup baik, 33\% menyatakan ada peningkatan dengan baik, dan 22\% menyatakan ada peningkatan dengan sangat baik. Hal ini didukung dengan persepsi mahasiswa kurang lebih sekitar $85 \%$ yang menyatakan bahwa belajar di program studi lain akan memperluas perspektif dan memberikan kompetensi tambahan yang dibutuhkan, $14 \%$ menyatakan ragu-ragu atau mungkin, dan hanya $1 \%$ menyatakan tidak tahu. Kebijakan program MBKM ini tentunya memberikan hak kepada mahasiswa untuk melakukan proses pembelajaran 3 (tiga) semester di luar program studinya, sehingga mahasiswa memiliki kesempatan untuk mengembangkan dirinya sesuai dengan minatnya. 

dan Mahasiswa - Abdul Kholik, Hasan Bisri, Zahra Khusnul Lathifah, Berliana Kartakusuma, Mustolah Ma'ufur, Teguh Prasetyo

DOI: https://doi.org/10.31004/basicedu.v6i1.2045

Kebijakan pembelajaran tiga semester di luar program studi ini diindikasikan berangkat dari sebuah konsep bahwa proses dan pengalaman belajar terjadi di mana saja dan berlangsung selama-lamanya (Lifelong learning). Selain itu, kebijakan MBKM juga memberikan pengalaman kepada mahasiswa untuk beradaptasi dengan budaya belajar atau kultur yang dikembangkan di institusi Pendidikan lain. Hal ini tentunya dapat meningkatkan kemampuan soft skills mahasiswa baik secara kognitif maupun empiris dan memunculkan sikap kompetitif-kolaboratif yang berlandaskan nalar ilmiah sehingga menghasilkan sikap adaptif baru terhadap profesi dan lapangan kerja baru. Selanjutnya, penerapan kurikulum MBKM juga harus diimbangi dengan proses berinovasi pembelajaran yang dilakukan tenaga pendidik misalnya dengan cara memadukan model pembelajaran PjBL, PBL, dan penggunaan media video pembelajaran dari youtube (Prasetyo \& Zulela, 2021).

\section{Dampak Implementasi Program MBKM terhadap Peningkatan terhadap Hard-Skill dan Soft-Skill}

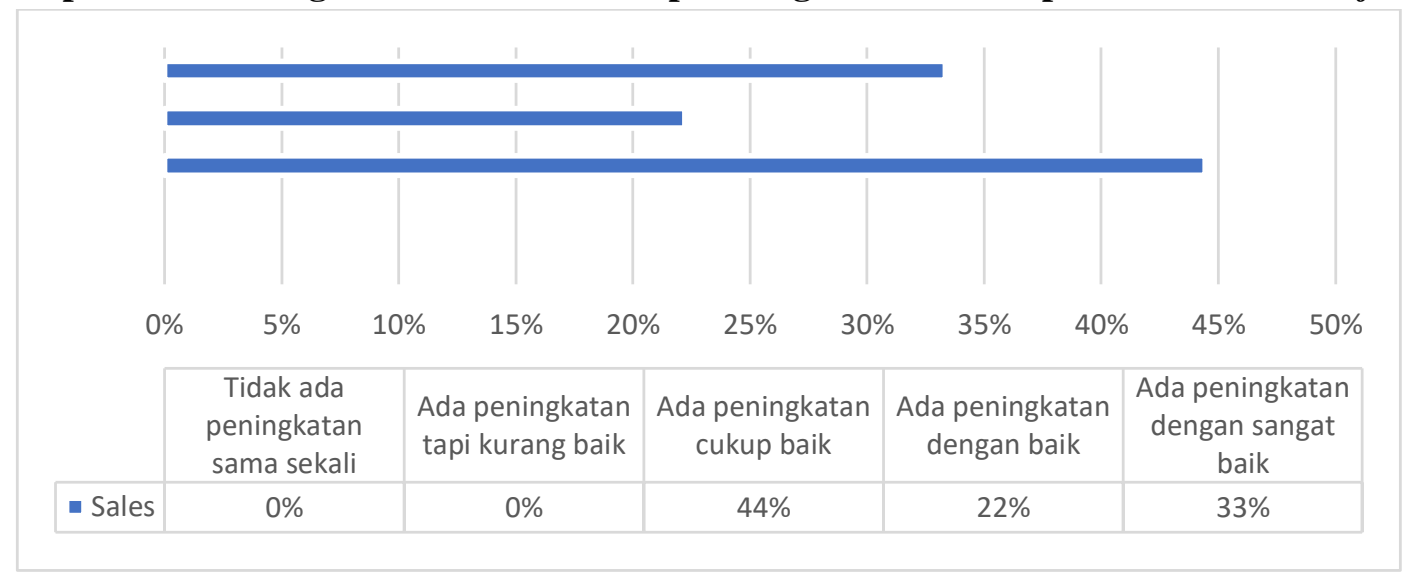

Diagram 4. Implementasi MBKM terhadap Hard-Skill Dan Soft-Skill Mahasiswa

Berdasarkan diagram di atas, mayoritas dosen MPI FKIP UNIDA Bogor menyatakan bahwa implementasi program MBKM memberikan peningkatan terhadap hard-skill dan soft-skill bagi mahasiswa. Sebanyak $44 \%$ menyatakan ada peningkatan cukup baik, $22 \%$ menyatakan ada peningkatan dengan baik, dan $33 \%$ menyatakan ada peningkatan dengan sangat baik. Hal ini senada dengan persepsi mahasiswa yang menyatakan bahwa ada peningkatan soft-skill yang diperoleh setelah mahasiswa mengikuti kegiatan MBKM dalam pengembangan kompetensi/keterampilan sebagai bekal bekerja setelah lulus, seperti terlihat pada diagram berikut:

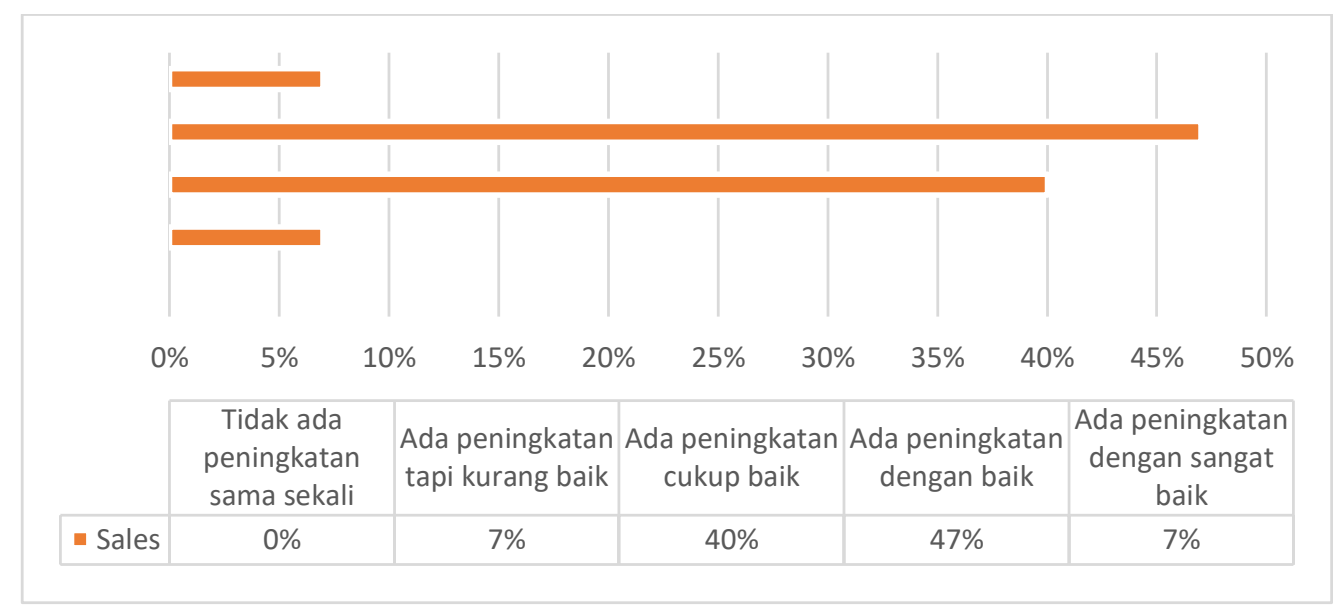

Diagram 5. Implementasi MBKM terhadap Hard-Skill Dan Soft-Skill Mahasiswa (2) 

dan Mahasiswa - Abdul Kholik, Hasan Bisri, Zahra Khusnul Lathifah, Berliana Kartakusuma, Mustolah Ma'ufur, Teguh Prasetyo

DOI: https://doi.org/10.31004/basicedu.v6i1.2045

Berdasarkan diagram di atas, 40\% mahasiswa dari 73 yang menjadi responden menyatakan ada peningkatan cukup baik dan $47 \%$ menyatakan ada peningkatan dengan baik. Hanya $7 \%$ saja mahasiswa yang menyatakan ada peningkatan tetapi kurang baik dan ada peningkatan dengan sangat baik. Selain itu, terkait kegiatan pembelajaran di luar kampus yang akan memberikan kompetensi tambahan seperti keterampilan dalam menyelesaikan permasalahan nyata yang kompleks, keterampilan dalam menganalisis, etika profesi, mayoritas mahasiswa MPI (79,4\%) mengetahui, dan 17,8\% merasa ragu-ragu, serta hanya 0,27\% yang menyatakan tidak tahu. Program MBKM yang dapat meningkatkan hard-skill dan soft-skill misalnya Kampus Mengajar. Program kampus mengajar ini dapat memberikan pengalaman mahasiswa, mengembangkan serta memberdayakan mahasiswa karena mahasiswa dapat melakukan proses mengajar langsung di kelas, adaptasi teknologi dan administrasi. Pelaksanaan kampus mengajar selama pandemi ini dilakukan dalam tiga bentuk pembelajaran yatu pembelajaran tatap muka, home visit, dan pembelajaran daring (Anwar, 2021).

\section{Hambatan-Hambatan Implementasi Program MBKM di Program Studi MPI}

Sesuai kebijakan, Program Studi bebas untuk melakukan penyesuaian kurikulum dan memberikan mahasiswa hak belajar 3 (tiga) semester di luar prodi. Berikut diagram yang menjelaskan hambatan-hambatan utama Program Studi MPI FKIP UNIDA dalam memberikan hak tersebut.

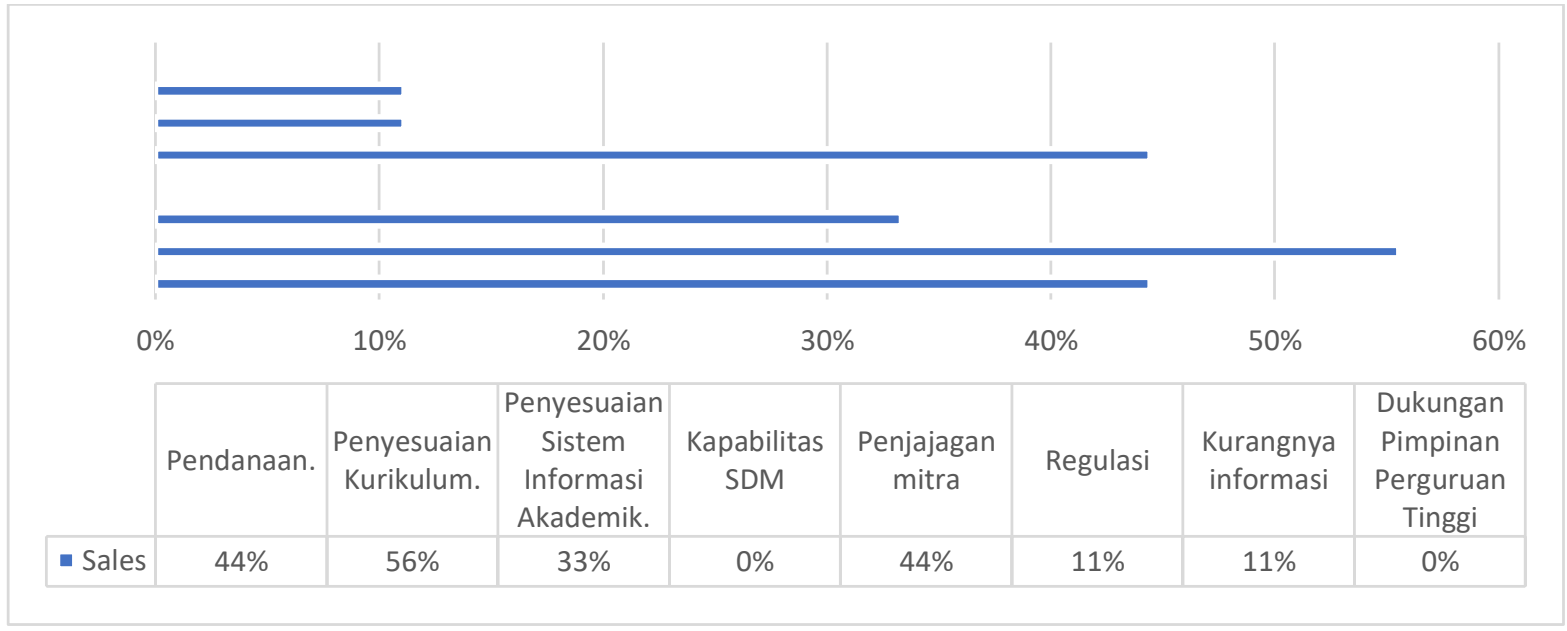

\section{Diagram 6. Hambatan-hambatan Implementasi MBKM di Program Studi}

Berdasarkan diagram di atas, banyak hambatan yang dirasakan program studi MPI dalam menjalan kebijakan program MBKM khususnya dalam memberikan mahasiswa hak belajar 3 (tiga) semester di luar prodi. 56\% responden menyatakan bahwa penyesuaian kurikulum, $44 \%$ terkait pendanaan, $44 \%$ penjajagan mitra, dan 33\% terkait penyesuaian sistem informasi akademik. Sisanya masing-masing hanya $11 \%$ yang menyatakan regulasi dan kurangnya informasi yang menjadi hambatan. Hambatan utama dalam mengimplementasikan kebijakan program MBKM khususnya dalam memberikan mahasiswa hak belajar 3 (tiga) semester di luar prodi adalah pada aspek penyesuaian kurikulum, pendanaan, penjajagan mitra, dan penyesuaian informasi akademik. Hal itu sesuai dengan apa yang disampaikan ketua program studi MPI bahwa "Sejak tahun 2020 prodi MPI sudah melakukan MoU dengan 5 prodi MPI Perguruan Tinggi di wilayah Bogor Raya, namun, sampai saat ini program MKBM telah memberikan kesempatan mahasiswa belajar di luar prodi belum terealisasi, diantara faktornya adalah sulitnya menyesuaikan kurikulum dan sistem informasi akademik".

Berdasarkan data-data yang telah diuraikan di atas, dapat dibahas bahwa implementasi pada aspek persiapan kurikulum MBKM, responden dosen MPI FKIP UNIDA sebesar 67\% dosen menyatakan mengetahui informasi adanya aktivitas MBKM tetapi kurang tertarik untuk mengikutinya kegiatan program 
MBKM sedangkan pada aspek mahasiswa sebesar 61,6\% menyatakan sudah menyiapkan diri untuk. Data ini menunjukkan perlu perbaikan pada aspek dosen dan mahasiswa. Hal yang senada berdasarkan hasil simpulan hasil program Merdeka Belajar-Kampus Merdeka tergolong pada kategori sedang berdasarkan aspek menerima, mengerti dan menilai pada Fakultas Ilmu Keolahragaan Universitas Negeri Semarang (Ardini et al., 2021). Data lain yang juga mendukung terkait persepsi program tiga semester di luar program studi, diperoleh data pada aspek pengetahuan memperoleh persentase sebesar $74,5 \%$, pada aspek penilaian memperoleh persentase sebesar $78,2 \%$ dan pada aspek sikap memperoleh persentase sebesar $80,2 \%$, artinya sudah banyak mahasiswa yang mengetahui, memahami, menilai dan menyikapi kebijakan hak belajar tiga semester di luar program studi dengan baik walaupun masih ada beberapa mahasiswa yang berkategori rendah (Aldo, 2021).

Program MBKM yang telah ditawarkan bahkan diimplementasikan oleh dosen dan mahasiswa di program studi MPI FKIP UNIDA diyakini memberikan dampak pada kapasitas kinerja dosen dan meningkatkan proses pembelajaran bersama mahasiswa. Hal ini ditunjukkan persepsi mahasiswa dan dosen meningkat pada aspek proses pembelajaran, hard-skill dan soft-skill. Misalnya pada Program kampus mengajar ini diharapkan dapat memberikan pengaruh positif bagi siswa, memantau guru dalam penyusunan perangkat pembelajaran dan guru demi meningkatkan pembelajaran di sekolah dasar (Hamzah, 2021). Program kampus mengajar ini sangat sesuai dengan tujuan kebijakan MBKM yang dicanangkan Kemendikbud yaitu meningkatkan kompetensi lulusan, baik soft skills maupun hard skills, agar lebih siap dan relevan dengan kebutuhan zaman, menyiapkan lulusan sebagai pemimpin masa depan bangsa yang unggul dan berkepribadian. Program-program experiential learning dengan jalur yang fleksibel diharapkan akan dapat memfasilitasi mahasiswa mengembangkan potensinya sesuai dengan passion dan bakatnya (Direktorat Kelembagaan dan Kerjasama Ditjen Dikti Kemdikbud, 2020).

Namun untuk mencapai tujuan dari kurikulum MBKM yang lebih maksimal tentu diperlukan sosialisasi yang mendalam terkait dengan penerapan konsep kampus merdeka belajar ini baik kepada para dosen maupun kepada seluruh masyarakat (Siregar et al., 2020). Jika melihat pada konsep pembelajaran yang dianut dalam kurikulum MBKM, ada tiga hal yang ingin dicapai berdasarkan filosofi progresivisme John Dewey. Tiga hal tersebut adalah (1) menghendaki adanya perubahan praktik pendidikan ke arah yang lebih maju, berkualitas dan modern; (2) adanya kemerdekaan dan keleluasaan lembaga pendidikan mengeksplorasi kecerdasan dan kemampuan peserta didik sesuai potensi, minat, dan kecenderungannya masing-masing peserta serta; (3) keleluasaan lembaga pendidikan dalam mengeksplorasi secara maksimal kemampuan, kecerdasan dan potensi peserta didik dengan cara yang fleksibel, natural, luwes, menyenangkan dan demokratis (Mustaghfiroh, 2020).

Tantangan ini harus disiapkan dengan baik karena merupakan hak belajar mahasiswa baik di program studi sendiri, di luar program studi, dan pengalaman belajar melalui kegiatan pertukaran mahasiswa, magang, KKNT, bakti sosial dan penelitian (Mariati, 2021). Mahasiswa merupakan calon pemimpin masa depan Indonesia harus ditantang untuk keluar dari zona nyamannya dan berlatih menghadirkan solusi dari masalah yang ditemui ketika berada di masyarakat serta adanya program MBKM ini juga dapat membantu mewujudkan desa-desa mandiri (Yanuarsari et al., 2021). Esensi dalam MBKM program pertukaran pelajar dan general education adalah memfasilitasi mahasiswa untuk bisa mengambil ilmu dari bidang keilmuan lain yang belum pernah dipelajarinya sehingga mahasiswa dapat berpikir secara luwes dan komprehensif (Faiz \& Purwati, 2021). Dengan adanya program pertukaran pelajar juga memberikan bekal dan penanaman karakter untuk mengenal suku, bangsa, budaya, ras dan agama sehingga memperkuat nilai-nilai persatuan dan kesatuan bangsa.

Berdasarkan hasil penelitian dari Puspitasari \& Nugroho, (2021) menyebutkan bahwa kendala-kendala yang dihadapi UPNVJT diantaranya pada saat melaksanakan kurikulum MBKM, adalah: 1) sulitnya mengkonversikan mata kuliah; 2) tidak mudah untuk mendapat mitra kerjasama dan melaksanakan kegiatan di 
luar prodi; 3) proses kerjasama antar PT yang rumit, karena pemahaman tentang program "MBKM" berbedabeda; 4) program dan kegiatan yang harus dilaksanakan dalam waktu singkat dan bersamaan; 5) sistem yang belum sepenuhnya siap menunjang program MBKM; 6) tidak ada kesesuaian waktu perkuliahan dengan kegiatan di luar prodi; 7) adanya kuota yang terbatas pada program pertukaran pelajar; 8) dosen pembimbing kurang menguasai program MBKM; 9) kurangnya dukungan dari mahasiswa; dan 10) masalah jaringan. Selain itu, pemegang kebijakan kurikulum MBKM dapat membantu mengadakan uji coba penelitian kelompok terbatas sebagai bahan evaluasi terhadap kebijakan MBKM yang dilakukan oleh tenaga pendidik dan lembaga pendidikan (Syarif, 2020).

Poin yang penting dalam pengembangan kurikulum MBKM di program studi wajib memperhatikan kompetensi inti mata kuliah wajib capaian profil lulusan dan mata kuliah pendukung. Merdeka Belajar merdeka merupakan proses pembelajaran secara alami atau natural untuk mencapai kemerdekaan secara individual (Saleh, 2020). Oleh karena itu, mahasiswa tidak merasa tertekan, tidak stress dengan permasalahan pribadi dan lingkungan, bebas berkreasi dan berinovasi, dan tidak ada belenggu. Keterbatasan dalam penelitian ini adalah masih kurangya responden dari mahasiswa yang memberikan respon terkait kuisioner yang dibagikan. Dari total jumlah 352 mahasiswa aktif, hanya $21 \%$ yang memberikan respon, dan sisanya sebasar $79 \%$ mahasiswa tidak memberikan respon terkait kuisoner yang dibagikan.

\section{KESIMPULAN}

Berdasarkan hasil penelitian dan pembahasan yang telah diuraikan bahwa implementasi kurikulum MBKM menunjukkan bahwa persepsi dosen dan mahasiswa telah dilakukan dengan sebaik-baiknya. Beberapa aspek menunjukkan bahwa dosen pada kegiatan penyusunan kurikulum MBKM telah berkontribusi dan berminat dalam program MBKM. Adanya peningkatan kapasitas dosen, perbaikan proses pembelajaran bersama mahasiswa, dan meningkatnya terhadap hard skills dan soft skills sebesar 33\% mahasiswa dengan kategori yang sangat baik. Namun perlu ditingkatkan pada segi kuantitas dan kualitas dosen dalam mengimplementasikan Kurikulum MBKM di program studi MPI FKIP UNIDA Bogor. Selanjutnya aspek mahasiswa terdapat antusias yang tinggi pada aspek persiapan sebesar $61,6 \%$ telah mempersiapkan diri untuk mengikuti program-program MBKM yang ditawarkan program studi dan Kemdikbud dan mahasiswa menyatakan bahwa ada peningkatan hard skills dan soft skills melalui program MBKM.

\section{UCAPAN TERIMA KASIH}

Penulis mengucapkan terima kasih kepada Sekretariat Ditjen Pendidikan Tinggi, Riset dan Teknologi, Direktorat Jenderal Pendidikan Tinggi, Riset dan Teknologi, Kementerian Pendidikan, Kebudayaan, Riset dan Teknologi yang telah mendanai kegiatan penelitian Program Studi Manajemen Pendidikan Islam (MPI) FKIP ini yang merupakan bagian dari Bantuan Pendanaan Program Penelitian Kebijakan Merdeka Belajar Kampus Merdeka dan Pengabdian Masyarakat Berbasis Hasil Penelitian dan Purwarupa PTS Tahun 2021. Terima kasih juga penulis berikan kepada Lembaga Penelitian dan Pengabdian kepada Masyarakat Universitas Djuanda Bogor yang telah memfasilitasi pelaksanaan penelitian ini.

\section{DAFTAR PUSTAKA}

Aji, R. H. S., \& Putra, M. H. I. (2021). Role Model Implementasi Kurikulum Merdeka Belajar Kampus Merdeka Pada Program Studi Non-Agama. Salam: Jurnal Sosial Dan Budaya Syar-I. Http://Journal.Uinjkt.Ac.Id/Index.Php/Salam/Article/View/23821

Aldo, L. O. (2021). Persepsi Mahasiswa Program Studi Pendidikan Teknik Bangunan Tentang Merdeka 

dan Mahasiswa - Abdul Kholik, Hasan Bisri, Zahra Khusnul Lathifah, Berliana Kartakusuma, Mustolah Ma'ufur, Teguh Prasetyo

DOI: https://doi.org/10.31004/basicedu.v6i1.2045

Belajar-Kampus Merdeka. Jurnal Applied Science In Civil Engineering. Http://Asce.Ppj.Unp.Ac.Id/Index.Php/Asce/Article/View/85

Anwar, R. N. (2021). Pelaksanaan Kampus Mengajar Angkatan 1 Program Merdeka Belajar Kampus Merdeka Di Sekolah Dasar. Jurnal Pendidikan Dan Kewirausahaan. Https://Journalstkippgrisitubondo.Ac.Id/Index.Php/Pkwu/Article/View/221

Ardini, S. N., Jayanti, I. D., Ulfah, M., \& ... (2021). Implementasi Program Merdeka Belajar Kampus Merdeka Di Universitas Pgri Semarang Tahun 2020-2021: Permasalahan Dan Solusi. Jp3 (Jurnal Pendidikan .... Http://103.98.176.9/Index.Php/Jp3/Article/View/10662

Baharuddin, M. R. (2021). Adaptasi Kurikulum Merdeka Belajar Kampus Merdeka (Fokus: Model Mbkm Program Studi). Jurnal Studi Guru Dan Pembelajaran. Https://Www.EJournal.My.Id/Jsgp/Article/View/591

Faiz, A., \& Purwati, P. (2021). Koherensi Program Pertukaran Pelajar Kurikulum Merdeka Belajar Kampus Merdeka Dan General Education. Edukatif: Jurnal Ilmu Pendidikan. Https://Www.Edukatif.Org/Index.Php/Edukatif/Article/View/378

Hasim, E. (2020). Penerapan Kurikulum Merdeka Belajar Perguruan Tinggi Di Masa Pandemi Covid-19. EProsiding Pascasarjana Universitas .... Http://Ejurnal.Pps.Ung.Ac.Id/Index.Php/Psi/Article/View/403

Mariati, M. (2021). Tantangan Pengembangan Kurikulum Merdeka Belajar Kampus Merdeka Di Perguruan Tinggi. Seminar Nasional Teknologi Edukasi Sosial Dan .... Https://Ceredindonesia.Or.Id/Index.Php/Sintesa/Article/View/405

Marisa, M. (2021). Inovasi Kurikulum "Merdeka Belajar" Di Era Society 5.0. Santhet:(Jurnal Sejarah, Pendidikan, Dan .... Https://Ejournal.Unibabwi.Ac.Id/Index.Php/Santhet/Article/View/1317

Mustaghfiroh, S. (2020). Konsep "Merdeka Belajar" Perspektif Aliran Progresivisme John Dewey. Jurnal Studi Guru Dan Pembelajaran. Https://Www.E-Journal.My.Id/Jsgp/Article/View/248

Prasetyo, T., \& Zulela, M. S. (2021). Proses Pembelajaran Daring Guru Menggunakan Aplikasi Whatsapp Selama Proses Pembelajaran Daring Guru Menggunakan Aplikasi Whatsapp. Jurnal Elementaria Edukasia, 4(1), 138-150. Https://Doi.Org/10.31949/Jee.V4i1.2769

Prihatsanti, U., Suryanto, \& Hendriani, W. (2018). Menggunakan Studi Kasus Sebagai Metode Ilmiah Dalam Psikologi. Buletin Psikologi, 26(2), 126-136. Https://Doi.Org/10.22146/Buletinpsikologi.38895

Puspitasari, R., \& Nugroho, R. (2021). Implementasi Kebijakan Merdeka Belajar Kampus Merdeka Fisip Upn Veteran Jawa Timur. Dinamika Governance: Jurnal Http://Www.Ejournal.Upnjatim.Ac.Id/Index.Php/Jdg/Article/View/2539

Sabriadi, H. R., \& Wakia, N. (2021). Problematika Implementasi Kurikulum Merdeka Belajar Di Perguruan Tinggi. Adaara: Jurnal Manajemen $\quad$... $\quad$ Https://Www.Jurnal.IainBone.Ac.Id/Index.Php/Adara/Article/View/2149

Saleh, M. (2020). Merdeka Belajar Di Tengah Pandemi Covid-19. Prosiding Seminar Nasional .... Http://Proceedings.Ideaspublishing.Co.Id/Index.Php/Hardiknas/Article/View/8

Siregar, N., Sahirah, R., \& ... (2020). Konsep Kampus Merdeka Belajar Di Era Revolusi Industri 4.0. Fitrah: Journal Of .... Http://Jurnal.Staisumatera-Medan.Ac.Id/Index.Php/Fitrah/Article/View/13

Sopiansyah, D., Masruroh, S., Zaqiah, Q. Y., \& ... (2022). Konsep Dan Implementasi Kurikulum Mbkm (Merdeka Belajar Kampus Merdeka). ... Social Laa Roiba ... Http://Www.Journal.Laaroiba.Ac.Id/Index.Php/Reslaj/Article/View/458

Suryaman, M. (2020). Orientasi Pengembangan Kurikulum Merdeka Belajar. Seminar Nasional Pendidikan Bahasa Dan .... Https://Ejournal.Unib.Ac.Id/Index.Php/Semiba/Article/View/13357

Susetyo, S. (2020). Permasalahan Implementasi Kurikulum Merdeka Belajar Program Studi Pendidikan 
748 Impelementasi Kurikulum Merdeka Belajar Kampus Merdeka (MBKM) Berdasarkan Persepsi Dosen dan Mahasiswa - Abdul Kholik, Hasan Bisri, Zahra Khusnul Lathifah, Berliana Kartakusuma, Mustolah Ma'ufur, Teguh Prasetyo

DOI: https://doi.org/10.31004/basicedu.v6i1.2045

Bahasa Indonesia Fkip Universitas Bengkulu. Seminar Nasional Pendidikan Bahasa Dan Sastra. Https://Ejournal.Unib.Ac.Id/Index.Php/Semiba/Article/View/13358

Suwandi, S. (2020). Pengembangan Kurikulum Program Studi Pendidikan Bahasa (Dan Sastra) Indonesia Yang Responsif Terhadap Kebijakan Merdeka Belajar-Kampus Merdeka Dan .... Seminar Nasional Pendidikan Bahasa Dan Sastra. Https://Ejournal.Unib.Ac.Id/Index.Php/Semiba/Article/View/13356

Syarif, M. I. (2020). Disrupsi Pendidikan Ipa Sekolah Dasar Dalam Menyikapi Merdeka Belajar Dan Kampus Merdeka Menuju New Normal Pasca Covid-19. Jurnal Basicedu. Http://Jbasic.Org/Index.Php/Basicedu/Article/View/487

Uswatiyah, W., Argaeni, N., Masrurah, M., \& ... (2021). Implikasi Kebijakan Kampus Merdeka Belajar Terhadap Manajemen Kurikulum Dan Sistem Penilaian Pendidikan Menengah Serta Pendidikan Tinggi. Jurnal Dirosah .... Http://Journal.Laaroiba.Ac.Id/Index.Php/Jdi/Article/View/299

Yanuarsari, R., Asmadi, I., Muchtar, H. S., \& Sulastini, R. (2021). Peran Program Merdeka Belajar Kampus Merdeka Dalam Meningkatkan Kemandirian Desa. Jurnal Basicedu. Https://Jbasic.Org/Index.Php/Basicedu/Article/View/1828 